\title{
EATING POTATO SALAD ON THE LAWN OF THE DAMNED
}

The very first Sunday that summer, I found out Zimmie wanted us to go to church with her. I moaned, kicked the stairwell. Kitty in the mirror threw a match on my funeral pyre, telling me Grandpa's coming with us. I moaned, flew back and forth in not-quite-circles. Grandpa usually just dropped Zimmie off at church, then cruised for an hour along right-handed blacktop lanes cleaving miles of gossiping cornfields. Although he was old and a smoker (living on borrowed time). But this Sunday he was going to put on a suit and come along; a terrible tragedy Zimmie couldn't drive.

Kitty posed at the hall tree, its greeny mirror diseased by time. She raised one foot, then the other, trying on angles. It mattered: yesterday she'd broken in new flats, wore them all day around the farmhouse with a pair of Grandpa's red hunting socks. Said: I think after, we're going to visit Claudette.

I moaned and flew, my hair a wild blonde flame throwing sparks across the foyer.

Church was all starch and lace, moist heat, moist sounds, programs adorned with doe-eyed Jesus fanning powdered-sugar faces slowly dissolving under delectable hats. Our grandmother Zimmie beamed and nodded all through the flydroning service. God was helium to Zimmie. Pumped her up every Sunday. She was light and happy most of the time anyway, although I have caught her, unawares, looking sucked up and airless, but I never let on; Zimmie rarely showed her hurts to the world. Basted and glazed her pain with happiness. Faked her way through life when she had to: fluent in bilingual body language. Sometimes hard to imagine she'd come out of a daredevil woman who'd stowed away from Ireland to America, ending up a suffragette, newspaper journalist, farm wife.

Grandpa was always saying that only stupid people were happy all the time. Which makes you, Moms, as he called Zimmie, one of the happiest people I know. And she'd peal with laughter. Although I knew her hurt burned under her lovely skin. I'd stand where Grandpa couldn't see me and put a whammy on him, blade of my hand between my eyes. A neat trick I learned from my twin brother.

He and I had been amputated that summer. It was our turn, we girls, to be farmed out, get sick on Black Cows, play Monopoly until we went blind or

THE IOWA REVIEW 
burst into tears, pick berries to freeze or sell, our mouths and fingers stained. Pitted mounds of berries with Zimmie's old hairpins, then rinse and wrap in cellophane and slatted pint containers to hawk out front by the road, M-106, splattered with apple guts, neighbors' cows musing, their hooves clamped to the grass. Could've been four-footed black and white jigsaw puzzles. Simply let echoing church bells and shrieking crows fly over their musing heads. (And just up that road, true love and redemption waited for us in the form of a Tilt-A-Whirl in a blazing carnival. But that's another story.)

Now in church, Zimmie sat pumped and happy with that holy helium. Kitty sat demurely next to her, practicing sitting-down poise, ankles and new flats crossed, left hand draped over right as the preacher bawled about the dangers of being wrapped up in one's appearance. It was the fool's gold era of Marilyn Monroe, of Hollywood cheesecake. Kitty, for the first time, was wearing a panty girdle and nylons, Tropical Tan, so exotic for a Michigan girl; what did some preacherman know about a sister's beauty?

Not all sisters. Straw-headed Sid sat on my right, her tongue rooting around where she'd lost a tooth. She was the youngest; we were eight, nine, twelve. Barricading us in, Grandpa took the aisle seat, beetling his righteous eyes at the congregation. A hundred paper Jesuses, fanning. Grandpa's fingers started tapping, so I knew he was just putting in time for when he could escape and light up.

But as soon as we joined the powdered throng shuffling out of the white clapboard church, Grandpa turned around to hustle us to his car, which he washed every Sunday morning, by himself, because children, especially girls, were not worthy of touching it, or even breathing on it. Child sweat annoyed him; menstruation seemed to mystify and terrify him. He was of that era. Anyway, his car was a gem. Brand-new 1960? Mercury Comet? I think it was. Cherry-cough-syrup red. Dressed every day in her best of whitewalls and red leather.

The flock was thick that day; we could not escape it, the women still fanning themselves with Jesus. We eased through their backsides contained within pastel dresses, backsides as curved as cellos. A foot army of sturdy pumps, impenetrable do's pinned under those confectionary hats. Gloved hands flashed in the air like small white birds.

Zimmie stopped every few steps to beam and exchange Mornin's, but I caught Grandpa's look and tugged on Zimmie's dress. Zimmie, Grandpa's waiting. 
Just a minute, sugar, I'm talking. The woman she was with bore a punchbowl hat covered in a light blue pelt adorned with trembling feathers. Perhaps about to take flight.

Zimmie, are we going to White Pine?

Just a minute, darlin'.

Are we going to White Pine to see Claudette.

The feathered woman stood back and flapped her dewlap. Oh! You're going there today?

Such a nice day for a drive, Zimmie nodded.

Truth was, if we didn't go see our sister, no one else would.

The feathered woman's gloved hand rose up to her pearls as if mention of my family would tarnish their luster. Heard Cassie had a new one, a boy.

Oh, that was two years ago.

Zimmie didn't add there was something wrong with him, too. He'd clamp his damp little hands to his ears and howl at every small thing, strangers, wind tearing at the eaves, a vase of our father's crocuses on the dining room table, even our Christmas tree.

Wouldn't open his presents, cried as if they singed him. Recently, a BandAid on my big toe sent him howling and rolling across the living room floor.

Zimmie broke away, beaming and waving goodbye, took me and Sid by hand and rendezvoused with Kitty and Grandpa, who had given up and lit a cigarette. His fierce eyes damning the fluttering, gabbling women. Hens, he snorted through a plume of blue smoke. Pudgy ones, at that.

Now, Dad, you heard the preacher. Beauty is only skin deep.

Hah. Put a paper bag over their heads, all women look the same.

Zimmie whooshed out a gasp, stepped back, almost on my foot. Put her gloved hand to her bosom. His remark sunk into our little-girl bones, immediately released its poison. The full effect not felt for a few years, but the process was started. Of course, Zimmie felt it right away: felt the venom shoot into her blue veins and turn them black.

Yet I knew at that moment her heart would not blacken, but had turned blazing ocher, the color of a grandmother's courage. She set her jaw and stepped between us and Grandpa.

He flicked his cigarette with his thumb. You done socializing with the whole damn town?

Zimmie's hand dropped. Don't curse in front of the children.

Oh, the deflections. 
I'm not a child, I blatted.

Yes, you are. Kitty swooped down, smoothed her Tropical Tans from ankles to knees.

I'm not! I'm nine!

Grandpa stabbed his cigarette at me. Hear that? This one says she's not a child.

My foot trembled to fly out and kick him. I have a name. And don't you say anything else about paper bags!

Too bad you're a girl; you'd make a good prosecutor.

I'm going to be an astronaut.

He shot smoke out of one nostril. Lord help us all.

Sid tugged on Zimmie's ropy wrist. Zimmeee, I'm thirsty.

We all are, sugar. Grandpa's going to stop at the A and Dubya on the way to White Pine, how 'bout that? Pretended to recover from Grandpa's toxic blow. Playfully clicked her false teeth at us. Zimmie lost all her teeth to a disease when she was eighteen, right after she had our Uncle Floid on Independence Day, 1916. Fireworks, a baby, and his mother's teeth fell out.

Grandpa's eyebrows flew apart. The A\&W? Who said?

Root beer floats for all! Zimmie dimpled, picked up her skirt and danced a flirty little jig, threw us a merry conspirator's wink. Oh, the deflections! Turned her shoulder on Grandpa. Which said everything.

But, the A\&W. We hurried out to the Comet, parked off by herself so no one could touch her. Grandpa helped Zimmie in, let us fend for ourselves. Sid sat up front almost on Zimmie's lap. Kitty and I had the back, she keeping a safe distance from my cooties. For all his hurry, Grandpa drove at a cruise, showing off his wheels: town square, town hall, the church twice, a church festooned with gingerbread and marzipan, right out of a Midwestern postcard.

Kitty exclaimed, I'm going to get married at this church. At your church, Zimmie.

That's wonderful, sweedart!

Kitty leaned forward. Grandpa. If Daddy is not around, will you give me away?

It would be the thrill of my life, Kittycat.

Thank you.

You're welcome, Toots.

I'm not getting married, I announced. 
Big surprise there, snorted Grandpa. Unless you find someone on Mars. I just might!

Zimmie threw her head back and cackled. She was playing some dumb hand game with Sid. Step on it, Dad.

Those floats aren't going anywhere.

They close early on Sunday.

Not this early. And I'm getting coffee.

Kitty leaned forward again. Can I have coffee, too?

Grandpa looked over Sid's thatch head at Zimmie, who looked back, then away, reached up and detached her pillbox hat from her head and poufed her salt-and-pepper hair, pinned up in rolls. When let down at night, lovely fairy princess hair she had not cut since World War II, a pact she'd made with God regarding her only son, captured by the Japanese. Early spring 1942, the Bataan Death March forever causing him aphotic, flyblown dreams. But Uncle Floid escaped, and Zimmie kept all her hair. Now she lay her hat in her lap and contemplated deeply in the side view mirror, so it was up to me.

She's too young, I blurted.

I am not. I'm twelve. I don't need root beer floats.

Shucks, fluttered Zimmie, I'm having one.

And you have Black Cows every day, I pointed out to my sister.

She turned on me with Grandpa's contemptuous glare. Addressed the front seat. That's not the point, Zimmie, I'm going to be a fashion model, so I have to be thin...ner. She ran her hands over her twelve-year-old baby fat. Smooth skin pudding. Please, Zimmie? Grandpa?

Grandpa aimed the car's red snout past Dancer's Drugs, the café, the infamous bowling alley and its tacked-on pool hall. Dens of iniquity, he snorted predictably. Moms. We going to let the girl have coffee?

Ask me when we get there.

Kitty sat back, her galaxy of freckles straining with hope, ambition. Wearing her dreams like a hair shirt trimmed with lace. Could not know that in three short stardusted years the light of her future would bend a hard left, launching her singing career.

Meanwhile, Zimmie turned to Grandpa and glowed at him in forgiveness. Girls, doesn't your grandpa look handsome today? Handsomer than a movie star!

Yes.

Yes. 
No, I said. Put a paper bag over their heads, all men look the same.

The Comet skewed across the broken white line, Grandpa's entire upper body whipping around. Jiminy Christmas! You little shit!

Dad!

Zip it, woman, and get me my pack from the glove box!

Zimmie pooched out her jaw, pulled off her gloves, curled them like fetuses, Sunday fetuses, inside her hat and handed it to me to set on the back windshield under an old chiffon scarf she kept there for that purpose. Unlatched the glove compartment and took out Grandpa's cigarettes. He furiously punched in the lighter. I felt a rush of homesickness for our father, Bob. When I rode with him-and I went with him everywhere-it was my job to push in the lighter and take it out when it was ready. I sat back, my chin quivering, very careful to stay out of Grandpa's line of sight in the rearview mirror. I missed my father. I missed my brother. They had no right to cut us apart. The car dipped in the road, rose up, and there, the A\&W hove up over the next rise. Grandpa pulled into the drive-thru, beetled his eyes at Zimmie.

Just this once, she said.

I expected him not to get me anything, but Grandpa aimed his fierce eyes at the girl in the window and growled Three large floats, two coffees. Lots of sugar and milk.

Kitty sipped her coffee like she was royalty, but my float was so heavenly, any envy evaporated with the foam. Sid made hers last for the whole ride to White Pine, even longer. I was a gobbler; in a family of seven children, you inhaled your food, or starved. One thing I could make last was a Slo Poke. My mother loathed them, hissed her disgust when she went snooping through my things and found the pilled corpse of a Slo Poke glued to my dresser or bed. She'd pry it off with a butter knife and fling it into the trash. But once I found one stuck under my rolltop desk, and it was still good.

Anyway. White Pine was a turreted Gothic castle sprawled across rolling green. Claudette had been living there for half of her retarded life; she was six now. Our parents did not go see her anymore. Wouldn't let us ask about her or talk about her. One sparkly January day they packed us up for a winter drive, which turned out to be to White Pine, where they wordlessly handed Claudette over to a statuesque blonde nurse. Our father, in red and black buffalo plaid, stood empty-armed looking very young, shell-shocked; it was our 
mother who chirped Well, goodbye! to her brain-damaged baby and turned on her heel and walked back out to the car.

Mornings before Claudette was put away, I used to scoot across my mattress, my knee grazing the sagging lump that was Sid on the top bunk, and stick out my leg and sweep my toes lightly across the top of Claudette's curly head.

You'll crush her soft spot, Kitty scolded. Her head will cave in.

I want her to know I'm here.

Well, tell her. She's retarded, not deaf.

Claudette hadn't changed much in three years. I couldn't believe she was six, still in crib and diaper. A changeling child. Idly scratching a mosquito bite on her forehead.

Did she look like me? She had my gappy grin. She blinked up at us; a turtle's eyes. Her crib just a step from a side door wide open to the summer day. Dust motes played with her stubby little toes. Had a lolling tongue that could do serious damage to my Slo Pokes.

I leaned over her, wondering if I could take her home. Sent her a mental invite. Would you like that? You can share my bed, Dad chopped up your crib and set fire to it in the yard. Threw the blankets and yellow ducky sheets into the flames' greedy suck and draw. Hauled springs and mattress to the city dump. While he was gone, our mother discreetly buried the baby bottles in her bathroom trash. The same way she hid her used sanitary pads and miniature whiskey bottles.

Claudette reached up cross-eyed for Zimmie who beamed at her, chords of sunlight playing in her peppery hair, in Claudette's maple sugar fluff. Zimmie clicked her dentures, Claudette gaped enthralled.

While we hung over the crib absorbing her, Grandpa propped himself outside the door and smoked, watched visiting families picnic on blankets among flowerbeds that looked like parade floats set in the grass. Picnics, at this place! Eating potato salad on the lawn of the damned.

Claudette watched us watch her until her eyes drooped shut and she drifted away. Kitty and Sid broke off to look at the other babies in their cribs, compare them to our sister; I hung over Claudette to soak her into my pores, prodding silently Will you come home with us? Hung nose to nose; without warning, she burbled, a deep chuckle like a man's. I looked up at Zimmie. What could she be dreaming about? Me?

She's laughing with the fairies and angels. 
Is she in retarded baby heaven?

Maybe.

But she's not dead.

She goes there in her dreams so she can run and play, like you children.

Oh. And Claudette blinked back to the ordinary world. Looked around and scratched. Warm sparks in her eyes: my sister a deserted house where a light had been left on, waiting for someone to come home.

Can we take her with us, Zimmie?

No, darlin'. She'll be here forever.

Grandpa heard, and moved out of the doorway to stand in the castle's shade.

The attendants were big-boned and black with soft voices, soft hands. Congenial and tolerant of us normal children. Even let Kitty bring in her coffee, Sid her root beer float. Mine was long gone. Beyond the door, picnickers pushed aside potato salad for fried chicken and biscuits. My stomach unleashed a ravenous growl.

While Zimmie stroked Claudette's humidity-curled hair and chatted to her in gentle twirly tones, Kitty and Sid wandered out to stand with Grandpa among peachblown butterflies and runaway flower petals. I hung in the doorway, shimmery in the July haze, the heat fragrant waves of juniper and pine. Looked back at my grandmother gazing down at my sister, Zimmie's face drooped with sorrowful love. She reached into the crib, her old lady arms shivering with the strain, lifted my sister out.

An attendant rushed over. Let me help you with her, missus!

I have her. Zimmie shakily cupped Claudette to her shoulder. The attendant hung back, watching with ready eyes. Then dove in and tugged the sheet taut. Zimmie buried her nose in Claudette's damp maple sugar fluff, murmured Poor, poor darlin'. Rocked her; shakily lay her back in the crib.

I shoved my glasses up, loped out the door, passed Grandpa and my sisters. Ran through picnickers happily chewing. Ran through the juniper air. Sid and even Kitty followed, trying to keep her new flats on her Tropical Tan feet, her outstretched hand holding aloft what was left of her coffee. Don't go far, hear? Grandpa called. I mean it.

Kitty stopped and smirked. He's worried about the Negroes.

I stopped short, panting in the heat. Shoved my glasses up. Sequined things too much like Zimmie's old lady spectacles swimming around my face. The Negroes! I think they're nice. 
So do I. But Zimmie and Grandpa are from Chattanooga, it's different down there. We Michiganeers don't care so much. She posed, sipped her coffee, looked around. We had stopped on a path twisting though a tunnel of pines, sweet in summer heat. Their shadows blue on our faces. Needles dark green silk. The dead ones washing around our church shoes. Kitty demurely lowered herself to the side of the path and took off one flat and shook it out, then the other. Ran her hand through her ripply auburn hair; she could've been our mother. Sid set her empty float cup on a stump and she and I jumped up and grabbed lower branches, trimmed of all stubs, almost planed smooth; each wrapped one knee around and began to twirl.

I'll keep an eye on the nuts, Kitty assured us. I hooted What nuts!, but she goggled her eyebrows at the upper floors of the castle. The nuts, up there.

I didn't get it.

By jumping, she scolded. If they didn't have bars on their windows, they'd jump. Kill themselves.

I stopped twirling to let my eyeballs roll back into place, shoved my glasses, squinted up at the windows, the demonic squint of the near-blind. The windows, to me, liquidy, hazy veined squares. Why would anyone kill theirselves?

Kitty shrugged. Some people just do. But Grandpa said they go to You Know, because only God decides when we die.

She, we, could not know that in thirteen years almost to the day, our father Bob would do that very thing, go out a window. The week of Kitty's wedding in Zimmie's church. Grandpa greatly mellowed, trapped at home with a nurse by dementia and amputated legs. Zimmie wearing her first-ever pantsuit with pillbox hat, as alive as I'd ever seen her, at both funeral and wedding. Me twenty-three and obese, married to a pothead sex addict. My twin brother in town from his artist's hideout in the Florida swamps where he lived among alligators by lantern light. Sid wandering across America in a broken suitcase. Our little brother declared schizophrenic. We had another little brother by then, a real joy. He'd grow up wise, brilliant, Goth.

Sid at eight twirled, called out People who kill theirselves go to h-e-double hockey sti-

Kitty barked Get down from there, those old men can see your underpants.

Sid plopped to her feet. Her hands mucked with pine sap. She swiped them on her ruffly church dress and looked around. We'd not seen the party 
of codgers in dusty seersucker inching through the pines. When they saw us watching them, they delicately stabbed their cane tips through the dead needles; one crabbed his knees to tip his hat at us, but we were not fooled.

Kitty stood up and brushed off her skirt. Let's go.

We drifted back to the castle, stopping at a circus-ring flowerbed to help ourselves to handfuls of frilly pinks blooming among spasms of tiny yellow things and flaming poppies. While Grandpa smoked and watched us, amused, we put the pinks in Kitty's coffee cup, filled it with water smelling of rotten eggs from an outside tap and took the flowers to our little sister in her crib, because it was the least we could do. 